\title{
Z Mistrzami podróż przez życie
}

\begin{abstract}
Abstrakt
Artykuł jest osobistą refleksją nad rolą Mistrza w życiu człowieka. Każdy człowiek napotyka na swojej drodze ludzi, którzy kształtują jego przyszłość. Nie zawsze jednak jesteśmy tego świadomi. Uświadomienie sobie roli innych ludzi w naszym życiu wprowadza pewien porządek w teraźniejszość i wpływa na kształtowanie własnej tożsamości. Poprzez podzielenie się opowieścią o swoich mistrzach i własnym pojmowaniu mistrzostwa chciałam przede wszystkim pokazać, że Mistrzami są przeważnie ludzie żyjący wokół nas, których często w codziennym życiu nie potrafimy dostrzec.
\end{abstract}

Słowa kluczowe: Mistrz, idol, poszukiwanie sensu życia, Marcin Kafar, Edward Stachura.

\section{A Journey through Life with Masters}

\begin{abstract}
This article is a personal reflection on the role of a Master in one's life. We all meet on our path people who in some way create our future. But we do not always realise it. Understanding their role in our lives allows us to implement order in our present life and impacts on our self-awareness. Through my stories about my masters and my own perception I wanted to show that often ordinary people, people around us that we might hardly ever notice or be aware of, are our true Masters.
\end{abstract}

Keywords: Master, idol, looking for a sense of life, Marcin Kafar, Edward Stachura.

\footnotetext{
* Społeczna Akademia Nauk w Łodzi, Wydział Nauk Społecznych i Humanistycznych.
} 


\section{Wprowadzenie}

Prezentowany tekst mieści się w obrębie badań narracyjnych w odmianie autobiograficznej. Czytelnicy znający to podejście, zapoznając się z kolejnymi akapitami mojej opowieści, odnajdą w niej tropy „analizy narracyjnej” zastosowanej na wzór proponowany przez narratywistów amerykańskich z kręgu Carolyn Ellis i Arthura P. Bochnera. Ten ostatni, tłumacząc, co mieści się pod pojęciem „analizy narracyjnej”, wyjaśnia, iż w tym wypadku: „wynikiem procesu badawczego jest opowieść - przypadek, biografia, opowieść o życiu, autobiografia czy też autoetnografia, które badacz konstruuje po to, aby przedstawić wydarzenia, bohatera i problemy, jakie podlegają badaniu. Tutaj zajmujemy się tym, co opowieść czyni, jak pracuje, jakie relacje kształtuje czy też animuje albo też tym, co sprawia, że ludzie zbliżają się do siebie i oddalają" (Bochner, Ellis 2016: 184-185).

Posługując się narzędziem w postaci analizy narracyjnej, zwracam się ku doświadczeniom osobistym przynależnym procesowi mojego stawania się tym, kim jestem w odniesieniu do trzech etapów życia: dzieciństwa, dorastania oraz młodości intelektualnej związanej $\mathrm{z}$ okresem rozpoczęcia studiów wyższych. W ten sposób staram się uchwycić i odczytać znaczenia dotyczące formatywnych aspektów mojej biografii. Zakładam, iż podlega ona zmianom w wyniku wchodzenia w relacje ze „znaczącymi innymi” - mistrzami, czyli ludźmi, którzy wywarli kiedyś bądź wciąż wywierają bardzo istotny (niekiedy wręcz przełomowy) wpływ na to, jak postrzegam świat i swoją w nim obecność traktowane - sięgnę do nomenklatury stosowanej przez Józefa Tischnera - jako wartości stanowiące wyzwanie (por. m.in. Tischner 2001).

Sądzę, iż moja propozycja przynajmniej roboczo mogłaby być określana mianem „pedagogiki uwrażliwionej duchowo”. Taka pedagogika byłaby wówczas pokrewna antropologii jako „ćwiczeniu duchowemu”, projektowi interesująco, a zarazem przekonująco przedstawionemu kilka lat temu przez znanego polskiego badacza Dariusza Czaję (2013). Najzwięźlej rzecz ujmując, antropologia jako ćwiczenie duchowe, ale też pedagogika o podobnym zabarwieniu, polegać miałyby na wyposażaniu praktyk akademickich w coś, co łączyć je będzie z szerokim, wielowymiarowym kontekstem „żywej egzystencji”. Dzięki temu ocalony zostaje także badacz jako człowiek, wraz z towarzyszącymi mu, o ile nie kluczowymi pod pewnymi względami, wewnętrznymi uwarunkowaniami jego działań, włączając w to różnorako kształtujące nas emocje i uczucia (tamże: 404-411).

Dla porządku dodam, że mój artykuł z założenia ma jedynie warsztatowy charakter, jest zaledwie wstępną próbą w sensie treściowym i konceptualnym zmierzenia się z tematem, nad którym mam zamiar dalej pracować. 


\section{Mistrzowie dziecięcego życia}

Gdy byłam małą dziewczynką, babcia opowiadała mi bajki. Wiem, że nie ma w tym nic nadzwyczajnego, jednakże moja babcia była wyjątkową kobietą, choćby dlatego, że nie opowiadała bajek czyichś, a tworzyła własne. Powstawały one zresztą często dopiero wtedy, gdy prosiłam, „Babciu, poopowiadaj mi...”. Pamiętam, jak kładłam się w śnieżnobiałej, wykrochmalonej pościeli, pokój zaś rozświetlało żółte, ciepłe światło nocnej lamki. Oczekiwanie na opowieść zawsze kryło w sobie tajemnicę, było zupełnie niezwykłą chwilą. W babcinych opowieściach występowało dużo kwiatów: kolorowych i pięknych, ale były też kwiaty chore, zwiędnięte, zniszczone i płaczące ludzkimi łzami. Dopiero dużo później zaczęłam zdawać sobie sprawę, iż zarówno mój wielki szacunek do przyrody, jak i swoista niechęć wobec wszystkich tych, którzy lekceważą prawa natury, w znacznej mierze wyrosły z zasłyszanych od babci opowieści. To jest coś, co zresztą trwa we mnie po dziś dzień, co odzywa się nawet $\mathrm{w}$ tym momencie, gdy zapisuję te słowa, kątem oka dostrzegam drzewo obsypane pięknymi, różowymi kwiatami i nagle przepełnia mnie z tego powodu trudna do wypowiedzenia radość, ale i smutek... tak bardzo przecież oczywiste... Babcia zmarła, kiedy miałam zaledwie 8 lat...

Wspomnienie o babci pracuje spiralnie, dzięki czemu moje myśli biegną teraz ku dziadkowi. Dziadek nigdy nie mówił zbyt wiele. Cichą, akceptującą postawą wobec wszystkiego, co było udziałem jego życia, wtapiał się w moje obrazy dzieciństwa, był ważną częścią przestrzeni widzianej oczami dziecka. Na tę przestrzeń składały się pola, łąki, rozświetlone słońcem drzewa, staw z kaczkami, górka, na której bawiłam się w dom... Dziadek - zamyślony, siedzący cicho na ławce przed domem - był trwałym wyposażeniem tamtego krajobrazu. Swoją niejako bezwiedną obecnością dawał mi nieprawdopodobne wręcz poczucie bezpieczeństwa. Gdy był blisko, mogłam swobodnie smakować świata, bo wiedziałam, że czuwa nade mną On - Dziadek. Inne żywe wspomnienie o dziadku jawi mi się jako długie zimowe wieczory przepełnione grą w karty i zabawą w sklep, słuchaniem muzyki... Dokonuję szybkich obliczeń; wynika z nich, że dziadek odszedł, gdy miałam 9 lat. Ja otoczona rodziną, już nie taka całkiem mała dziewczynka, czułam się wówczas bardzo, bardzo samotna...

Pustki po ukochanych dziadkach długo nikt nie potrafił wypełnić. Zastanawiam się, czy gdyby oni żyli, kiedy dorastałam, to moje życie potoczyłoby się tak samo? Czy dzięki ich nienachalnie przekazywanej mi mądrości byłoby łatwiejsze, mniej buntownicze? To na zawsze już pozostanie tajemnicą. Tym niemniej jestem szczęśliwa, że dane mi było ich poznać; choć byli w moim życiu jedynie gośćmi, to ich wizyta pozostawiła we mnie ślad, który - to pewne! - nigdy nie zostanie zatarty. Odstęp kilkudziesięciu lat sprawia zaś, że mogę dostrzec i zrozumieć, jak wiele dla mnie uczynili - Oni, niespełnieni do końca mistrzowie mojego dzieciństwa... 


\section{Idol i mistrz - w stronę Stachury}

Weszłam do pokoju uroczej nastolatki. Z plakatu wiszącego na wewnętrznej stronie drzwi popatrzył na mnie rockowy muzyk. W mroku pokoju cicho płynęła muzyka. Eliza siedziała po turecku. Była ubrana w czarne, obcisłe spodnie i czarną luźną koszulę. Przeguby jej dłoni ozdabiały kolorowe plecionki. Długie włosy opadały na ramiona, zakrywając jej twarz. Pomyślałam: „Jak bardzo przypominasz mnie samą, sprzed kilkunastu lat". Usiadłam obok niej. Mówiłyśmy niewiele, skupiając się na słuchaniu muzyki. Gdy wyszłam z pokoju, uśmiechając się do siebie, zanuciłam piosenkę Grupy pod Budą:

Ja do szkoły chodziłam w glanach, z flanelową koszulą na wierzch, a z walkmana leciała Nirwana, od poranku po szary zmierzch. Tamten facet grał takie nuty, że się chciało odlecieć z nim, za horyzont przez jesień zasnuty lub ze skręta niebieski dym. Sprawa znana od pokoleń, których tyle już ubyło, że zmieniają się idole, ale wciąż ta sama miłość...1

Fascynacja idolem to istotny rozdział w życiu dorastającego człowieka, który poszukuje wzorców do naśladowania. Informacje o idolu pozyskuje z gazet, telewizji czy w obecnych czasach z Internetu. Młody człowiek do pewnego stopnia żyje życiem idola, śledzi na bieżąco wszystko to, co dzieje się wokół konkretnej postaci. Zauroczenie idolem może nagle wygasnąć lub przerodzić się w kolejną fascynację. W sprzyjających okolicznościach idol może stać się kimś więcej aniżeli tylko postacią godną naśladowania. Mając kilkanaście lat, człowiek poszukuje zrozumienia świata, w kulturze euroamerykańskiej to ostatnie często przychodzi do niego poprzez obcowanie z muzyką i poezją. Nie wiem, jak obecnie młodzież postrzega np. przestrzeń ją otaczającą, wiem natomiast, jak wyglądało to wtedy, gdy dorastało moje pokolenie. „Szarość” miejsca, gdzie mieszkałam, była wręcz przygnębiająca. Wszystko wokół było „szare”: dom, szkoła, przystanek i autobus wiozący do szkoły. W świecie, w którym żyłam, nie dostrzegałam niczego, co dawałoby nadzieję na inną, „kolorową” jakość wychyloną ku przyszłości. Chyba nawet nie podejmowałam próby odkrycia owej odmiennej jakości; trwałam pogrążona w marazmie dnia codziennego, podświadomie będąc przekonaną, że i tak nic się nie zmieni. Myliłam się jednak. Uśmierzenie egzystencjalnego bólu nastolatki przyszło znienacka, a stało się to za sprawą tekstów Edwarda Stachury. Zanurzając się w jego twórczość, z jednej strony stawałam się jeszcze bardziej samotna, z drugiej zaś strony wiedziałam, że wreszcie odnalazłam kogoś, kto mógłby zrozumieć, co przeżywam.

\footnotetext{
${ }^{1}$ Fragment piosenki Grupy pod Budą pt. Ta sama miłość pochodzi ze strony internetowej zespołu: http://www.podbuda.pl/p.php?zaw=komponenty\&id_kom=piosenki\&id_piosenki=198; słowa napisał Andrzej Sikorowski.
} 
Teksty Stachury działały siłą zawartego w nich ogromu rozpaczy, idealnie odzwierciedlającego niepokoje młodego, zagubionego pokolenia i cechujących je „rozedrganych" emocji. Stachura wydawał się być skrajnie autentyczny w tworzonej przez siebie poezji i prozie, autentyczności zaświadczał też w swych dziennikach; to powodowało, że stopniowo - w trakcie uskutecznianej lektury - stawał się moim mistrzem. Najprościej rzecz ujmując, Stachurowe mistrzostwo polegało na dzieleniu się darem współdoświadczania rzeczywistości, w której zmuszona byłam funkcjonować, i jej doskonałym „przekładzie” na słowa, z którymi łatwo było się utożsamić. Stachura mówił językiem scalania w jedno tego, co przeminęło, tego co jest i tego, co dopiero nadejdzie:

Chodź człowieku, coś ci powiem

Chodźcie wszystkie stany

Kolorowi, biali, czarni

Chodźcie zwłaszcza wy, ludkowie

Przez na oścież bramy

Dla wszystkich starczy miejsca

Pod wielkim dachem nieba (Stachura 2007: 58).

Dzięki takim jak powyższe frazom odnajdywałam wewnętrzny spokój, mówiąc patetycznie - roztapiałam się w komunii dusz. Nikt tak jak Stachura nie umiał pojąć smutku człowieka zagubionego i nieustannie poszukującego. Dodatkowo, potrafił ów nieprzebrany niekiedy smutek przedziwnie, niewytłumaczalnie unieść prostym zdaniem w stylu: „Rozdzierający jak tygrysa pazur antylopy plecy jest smutek człowieczy" (tamże: 88). Język, którego używał Stachura, chyba dla każdego, kto spotykał się z jego literaturą, był czymś nieoczywistym. Czytanie jego tekstów było wyzwaniem ze względu na umiejętność posługiwania się nietypową, mocno abstrakcyjną formą. W wielu utworach pojawiały się niezrozumiałe, a zarazem niebanalne sformułowania, jak np. „pudowy kamień" ${ }^{2}$, co budziło zapewne nie tylko u mnie intelektualną ciekawość. Aczkolwiek, poza wszystkim innym, Stachura był kimś mi bliskim, kimś, z kim chciało się po prostu być. Czytając Stachurowe dzienniki, dowiadywałam się, co ich autor lubił, za czym bądź za kim tęsknił; dowiadywałam się wiele także o emocjach, jakie nim targały - widziałam jego obraz, w którym, to bodaj najważniejsze, mogłam odnaleźć część siebie. Ze Stedem ${ }^{3}$ można było płakać - i śmiać się. Kiedy czułam się wyalienowana, krzepiącą stawała się myśl, że gdyby Stachura żył, mógłby odczuwać podobnie jak ja, szerzej - jak moje pokolenie; „Chodzę tu, chodzę tam, w tłumie ludzi jestem sam” (Stachura 1997: 44). Wojskowy plecak, a w nim zniszczony egzemplarz Fabula rasa4 ${ }^{4}$, pożółkłe kartki, postrzępiona

\footnotetext{
2 Pudowy - od słowa „pud” - jednostki masy używanej w Rosji i Królestwie Polskim. Jeden pud odpowiada $16,38 \mathrm{~kg}$.

${ }^{3}$ Sted - tak mówili do Edwarda Stachury przyjaciele.

${ }^{4}$ Fabula rasa, powieść Edwarda Stachury.
} 
okładka imitująca jeans i poruszający się po meandrach wyobraźni wizerunek mistrza, także występującego, jakże by inaczej?, w odcieniach wszechobecnej „Szarości”. Szłam drogą, wokół której rozciągały się czarno-białe pola, wiał zimny wiatr, jednakże podarte spodnie i sznurkowy biały sweter oraz skórzana powycierana kurtka były świetną kreacją na każdą porę roku. „Ubieranie się w smutek” było w pewnym sensie formą podkreślania strojem własnej indywidualności. Istotnym było, by „szarością wyróżniać się z szarości” - ot taki paradoks. Wszyscy „tragiczni i legendarni" 5 byli dla mnie ważni, jednakże pośród nich to Stachura był najważniejszym spośród ważnych. Zastanawiam się, czy w największym stopniu nie stało się to przez to, iż odnalazłam w jego dziełach to, co teraz nazwałabym szacunkiem dla zwyczajnych ludzi... Otwieram dzienniki i czytam: „Patrzę na zwyczajnych ludzi, do których mnie zawsze tak bardzo ciągnęło, nad twardym losem których tak bardzo cierpiałem, których tak bardzo kochałem, i teraz jeszcze więcej w biedzie mojej kocham ich" (Stachura 1998: 49). Czy mistrz nie powinien być dla ludzi i z ludźmi? Czy nie powinien spełniać warunku dawania świadectwa współistnienia z innymi? Taki był właśnie Stachura-autor, którego poznałam i odkryłam dla siebie.

Jakże biedny jest człowiek i jakże dzielny w swojej biedzie. Samiuteńki w świecie i chyba we wszechświecie. Posiada świadomość i słowa, za pomocą których nie może porozumieć się z przyrodą ani ze światem nadprzyrodzonym, który mnie słucha, ale nie odpowiada w sposób wyraźnie słyszalny, widzialny, dotykalny na słowa modlitewne od tysiąca lat wypowiadane, szeptane, śpiewane czy w rozpaczy krzyczane. Jakże zahartowany w swojej biedzie jest człowiek (Stachura 2000: 66).

Mistrzowie z lat młodości dają możliwość podróży w czasie. Gdy zanurzam się we wspomnieniach, widzę siebie siedzącą przy stoliku w ponurej restauracji z bliskim dla mnie człowiekiem, przy wspólnej szklance herbaty. Na dwie nie było nas stać. W myślach spaceruję po parku z koleżankami i kolegami. Proszę kolegę o pożyczenie tomiku poezji z 1974 r. z pięknymi wierszami Bolesława Leśmiana. Nieoczekiwanie tomik staje się moją własnością. Teraz, gdy kieruję wzrok na pomarańczową książeczkę pt. Wybór poezji polskiej, wierszu, rodzona moja mowo, pojawia się uśmiech na mojej twarzy. Cieszę się, że urodziłam się w czasach, w których rozmowy w cztery oczy, spacery, czytanie nie były zmącone dźwiękiem smsów, maili, telefonów. To stwarzało zupełnie inną perspektywę postrzegania otoczenia. Człowiek dojrzewający to człowiek na różne sposoby cierpiący, widzący swoje nieszczęście jako najbardziej tragiczne i wyjątkowe. Mistrzowie to ci, co otwierają

\footnotetext{
${ }^{5}$ Zwrot zaczerpnięty z książki pt. Tragiczni i legendarni Jana Marxa, odnoszący się do poetów, takich jak: Halina Poświatowska, Rafał Wojaczek, Andrzej Bursa, artystów, których twórczość nieodzownie związana była z kruchością ich życia.
} 
przed nim nowe horyzonty. Dla wielu, jeśli nie dla większości z nas, wraz z ukończeniem szkoły, symbolicznym przejściem do dorosłego życia, przygoda z mistrzami/Mistrzami kończy się. Niektórzy mają jednak więcej szczęścia i do nich zaliczam się ja. Mistrzowie z czasów młodości w pewnym sensie przygotowali mnie do tego, co wydarzyło się w późniejszym etapie mojego życia.

\section{Spotkać mistrza nauczyciela}

Natrafiłam kiedyś na przysłowie mówiące o tym, że mistrz pojawia się wtedy, gdy uczeń jest gotowy6. Ta gotowość rodzi się z nieco innej potrzeby niż li tylko znalezienie pokrewnej duszy, pomagającej - choćby pośrednio, za pomocą literatury - odnaleźć się w zawiłościach nastoletniego dorastania. Tym razem sprawa dotyka sfery całkiem świadomego już dążenia do osobistego rozwoju. Sądzę, iż przynajmniej w niektórych wymiarach rozwój ten nie byłby możliwy lub przynajmniej pozostałby mocno utrudniony bez obecności mistrza jako osoby zdolnej oddziaływać na nas w sposób pozwalający na prawdziwie twórczo-budujące samoodniesienia (te samoodniesienia to inaczej akty refleksywne, ponawiane w toczącym się nieustannie procesie zyskiwania „samowiedzy poznawczej” (por. Kafar 2017)).

Decyzję o kontynuacji studiów po kilku latach przerwy traktuję jako w dużej mierze zwrotną. Podejmując ją, zastanawiałam się, czy będę umiała przeobrazić ją w coś faktycznie usensawniającego mój wybór. Znajdowałam się wówczas w takim momencie życia, w którym potrzebowałam inspiracji i drogowskazów. Dominowała we mnie chęć wybicia się z mentalnej pustki, powoli podmienianej przez wzrastającą chęć na życie: „Wędrówką jedną życia jest człowieka: Idzie wciąż, Dalej wciąż... Dokąd? Skąd? Jak chmura zwiewna życie jest człowieka: Płynie wzwyż, Płynie wniż, Śmierć go czeka. To nic! Dopóki sił, Trzeba żyć, Będę żyć!” (Stachura 1998: 14), powtarzałam, przygotowując się na kolejną konfrontację ze światem. Wszechogarniające mnie momentami Rozpacz, Smutek, Żal spowodowane współuczestnictwem w chorowaniu bliskiej mi osoby zaczęły nabierać nowego wyrazu za sprawą tekstów Marcina Kafara. Eseje autobiograficzne, takie jak chociażby: Żyć i umierać w nadziei. Moralno-religijne aspekty choroby terminalnej (Kafar 2010a), Bliskie relacje $w$ doświadczaniu choroby terminalnej i żałobie (Kafar 2010b), O odchodzeniu najbliższych. Przyczynek do antropologii osobistej (Kafar 2010c), a przede wszystkim książka pt. $W$ świecie wygnańców, wdów i sierot. 0 pewnym wariancie antropologii zaangażowanej (Kafar 2013), opowiadały o zmaganiach ich autora z podobnymi do moich doświadczeniami. Lektura tych prac okazała się być pod wieloma względami rozświetlająca, to jednak, co uważam w niej za fundamentalne, sprowadzało się do pokazania mi, jak niedocenianą wartością jest - paradoksalnie - wychodzenie poza własne doświadczenie. Bycie sobą rodzi się w akcie przekraczania

${ }^{6}$ Autor nieznany, przysłowie prawdopodobnie chińskie. 
siebie, własnych ograniczeń; to właśnie przesłanie stało się dla mnie kluczem do poznania obszarów wcześniej egzystencjalnie „mglistych” i trudnych „do pojęcia”, obszarów, które wzbudzały we mnie zarazem lęk i fascynację.

Pomimo tego, że spędziłam wiele godzin na zgłębianiu pasjonujących osobistych historii, to wciąż nie wiedziałam, czy właściwie interpretuję słowa Marcina Kafara. Czułam, że sama nie jestem w stanie dalej unieść tej wiedzy, że odkrywanie kolejnych, ukrytych między wierszami wymiarów staje się zbyt trudne. Zdarza się przecież, że sięgamy po książkę, ale jeśli treści w niej zawarte nie są dla nas wystarczająco zrozumiałe, odkładamy ją na później, podejmując ryzyko, że nigdy nie nadejdzie właściwy moment, by zmierzyć się ponownie z ciekawym, ale zbyt trudnym dla nas zagadnieniem. Będąc w takiej właśnie sytuacji, zdecydowałam się na bezpośrednie spotkanie $\mathrm{z}$ autorem $W$ świecie wygnańców, wdów i sierot. Do końca nie byłam pewna, czy wypada poprosić o konsultacje, zajmować czas swoją osobą. Byłam jednak przekonana, że rozmowa z człowiekiem, który swoimi tekstami znacząco wpłynął na mnie, jest mi potrzebna. Nie oczekiwałam „prowadzenia za rękę", nie rościłam sobie prawa do ewentualnych kolejnych intelektualnych spotkań, jedynie przeczuwałam, iż ta rozmowa sprawi, że uzyskam odpowiedź na nurtujące mnie pytania. I tak też się stało, a niniejszy esej zaświadcza o tym, że tamta rozmowa miała i ma swój dalszy ciąg.

\section{Zamiast zakończenia: Czy potrzebni są mistrzowie?7}

Jeśli uczeń i mistrz patrzą w tę samą stronę, obaj mogą liczyć na to, że wcześniej czy później na horyzoncie otworzą się przed nimi nowe - wspólne - przestrzenie poznania. Gdy myślę o tym, że podczas minionych lat mogłam nie spotkać żadnego z moich mistrzów - tych, których wymieniłam, a także tych, o których nie wspomniałam w swoich rozważaniach, widzę siebie jako człowieka ubogiego. Żeby móc się rozwijać, trzeba nauczyć się czerpać z wiedzy i mądrości innych. Poruszanie się jedynie w kręgu własnych myśli bywa wielką przygodą, ale nie jest ono wystarczające do prawdziwego poznania zarówno siebie, jak i innych ludzi. Zamykając się w zakamarkach własnego doświadczenia, można ulec złudzeniu, że są one unikatowe. Na powtarzalność słów trafnie zwrócił uwagę Michał Rydlewski w artykule pt. Wszyscy jesteśmy wymyśleni, odwołując się do następującej konstatacji Marka Hłaski: „Nikt nie ma własnych słów. Wszyscy powtarzają te same świństwa od tysięcy lat" (Hłasko 1993: 196, za: Rydlewski 2016: 142). W moim pojmowaniu mistrzostwa, mistrza zaczyna się dostrzegać wraz z budzącą się w nas ciekawością, otwartością i wrażliwością w stosunku do innych ludzi. O autentyczności mistrza zaświadcza jego stosunek względem tego, dla kogo występuje on jako mistrz.

\footnotetext{
${ }^{7}$ Nawiązuję do artykułu pt. Mistrzowie - preliminaria. O założeniach pewnego projektu badawczego (Kafar, Kola 2016).
} 
Wszelako dopełnienie mistrzostwa dokonuje się w żywej relacji, przekraczającej wymiar choćby i najmądrzejszych ksiąg. Swoim współistnieniem z innymi mistrz daje świadectwo własnego człowieczeństwa. Nie obawia się i nie wstydzi kontaktu z uczniem - jest ciekawy, czy i czym wiedza, którą mu podarował, zaowocuje. Mistrz czasów współczesnych jest (powinien być?) więc człowiekiem z krwi i kości, kimś obecnym pośród innych ludzi. Jest otwartą księgą, w której póki żyje, będzie dopisywał kolejne rozdziały, z którymi uczeń, w razie potrzeby, będzie mógł się zapoznać. W moim przypadku mistrzowie uwalniali mnie $\mathrm{z}$ nagromadzonych emocji, stymulowali moje myślenie, w ten sposób kształtując mnie jako człowieka. W dorosłym życiu potrzebowałam mistrza, który będzie potrafił wypowiedzieć to, czego ja nie umiem wypowiedzieć i - wzbudzając coś w rodzaju intelektualnej

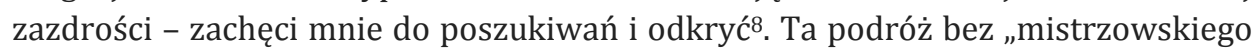
oka" byłaby jedynie tułaczką po interesujących mnie obszarach wiedzy. Mistrz pokazuje i toruje drogę do wolności, pozwala rozpoznać nieznane wcześniej ścieżki, pozwala też po nich błądzić. Mistrza można spotkać jedynie w drodze. Droga skłania do poszukiwań, a nawet przymusza do nich, w sprzyjających okolicznościach stając się budującym nas wyzwaniem. Mistrzowie są potrzebni wszystkim, nawet mistrzom. Nauczyłam się również, że jeżeli jest nam dane spotkać na swojej drodze mistrza, z którym odczuwa się wyjątkową nić porozumienia, to nie należy bać się podążać za nim; warto zaufać poecie, powiadającemu: „kto wiecznie błądzi - wiecznie znajduje i nigdy do celu nie zabłądzi” (Stachura 2007: 106).

\section{Bibliografia}

Bochner A. P., Ellis C. (2016) Evocative Autoethnography. Writing Lives and Telling Stories, New York, Routledge Tayler \& Francis Group.

Czaja D. (2013) Antropologia jako ćwiczenie duchowe w: Znaki szczególne. Antropologia jako ćwiczenie duchowe, Kraków, Wydawnictwo Uniwersytetu Jagiellońskiego, s. 395-420.

Kafar M. (2010a) Żyć i umierać w nadziei. Moralno-religijne aspekty choroby terminalnej w: Nie czas chorować? Zdrowie, choroba i leczenie $w$ perspektywie antropologii medycznej, D. Penkala-Gawęcka (red.), Poznań, Wydawnictwo Biblioteka Telgte, s. 177-194.

Kafar M. (2010b) Bliskie relacje $w$ doświadczaniu choroby terminalnej i żałobie w: Doświadczenie choroby $w$ perspektywie badań interdyscyplinarnych, B. Płonka-Syroka, M. Skrzypek (red.), Wrocław, Wydawnictwo Medyczne Akademii Śląskiej, s. 353-366.

\footnotetext{
${ }^{8}$ Jak dotychczas, te poszukiwania i odkrycia znalazły wyraz m.in. w pracy magisterskiej pt. Opieka nad osobq bliskq z problemem zanikającej pamięci. Na przykładzie rodzin osób chorych przebywających w ośrodku „Nasz Dom”, Łódź 2017, napisanej pod kierunkiem dr. Marcina Kafara.
} 
Kafar M. (2010c) O odchodzeniu najbliższych. Przyczynek do antropologii osobistej w: Antropologia zaangażowana(?), Zeszyty Naukowe Uniwersytetu Jagiellońskiego, Prace etnograficzne, zesz. 38, F. Wróblewski i in. (red.), Kraków, Wydawnictwo Uniwersytetu Jagiellońskiego, s. 157-166.

Kafar M. (2013) W świecie wygnańców, wdów i sierot, Łódź, Wydawnictwo Uniwersytetu Łódzkiego.

Kafar M. (2017) Zyskiwanie samowiedzy poznawczej jako proces edukacyjny, „Nauki o Wychowaniu. Studia Interdyscyplinarne", nr 1(4), s. 270-284.

Kafar M., Kola A. F. (2016) Mistrzowie - preliminaria. O założeniach pewnego projektu badawczego, „Nauki o Wychowaniu. Studia Interdyscyplinarne”, nr 1(2), s. 190-196.

Rydlewski M. (2016) Wszyscy jesteśmy wymyśleni w: Auto/biograficzne aspekty praktyk poznawczych, M. Kafar (red.), Łódź, Wydawnictwo Uniwersytetu Łódzkiego, s. 127-146.

Stachura E. (1997) Zobaczysz, Warszawa, Wydawnictwo Sternik.

Stachura E. (1998) Postrictum, Warszawa, Wydawnictwo Kurpisz i Pogonowski.

Stachura E. (2000) Fabula rasa, Warszawa, Wydawnictwo C\&T.

Stachura E. (2007) Gdziekolwiek jesteś, Toruń, Wydawnictwo Adam Marszałek.

Tischner J. (2001) Etyka wartości i nadziei w: A. Kłoczowski, J. Tischner, Wobec wartości, Poznań, Wydawnictwo W Drodze, s. 9-132. 